\title{
Environmental Surveillance and Vaccine Derived Polio Virus type 2 Isolation, Gombe State, Nigeria.
}

\section{Raymond S. Dankoli}

World Health Organization (W.H.O), Gombe, Gombe, Nigeria

Objective

To evaluate Vaccine Derived Polio Virus 2 isolation rate from Environmental Surveillance and its contribution to Polio Eradication Initiative (PEI)

\section{Introduction}

Nigeria is the only country in Africa yet to be certified free of Wild Polio Virus (WPV). The country consists of 36 States and a Federal Capital Territory. Gombe is one of the 19 Polio high risk States in the North-eastern geo-political zone of the country. The last case of WPV isolated in Gombe State was in 2013.

One of the strategies for Polio eradication is a sensitive Acute Flaccid Paralysis (AFP) surveillance system in which any AFP is promptly detected and timely investigated. The focus of the investigation is to analyze two faecal samples of the patient, and/or sometimes those from contacts for any possible isolation of Polio Virus [1] (PV). AFP surveillance is meant to be applicable to any human population at any time; however, there are situations in which there are good reasons to suspect that negative results of AFP surveillance are not reliable. Supplementary information is required in such situations and one approach for that is Environmental Surveillance (ES), in which a search for PV is made in environmental specimens contaminated by human feaces [2] ES in the African region started in Nigeria in July 2011 [3,4]. Since the introduction of this strategy, it has achieved its objective of complimenting the AFP surveillance system. There has been a gradual increase in the number of ES sites in Nigeria from 2011 to date4. The increase is largely due to the successes recorded in terms of the PV isolation from the sites, PV epidemiology, the large population size and mobility [4,5]. The last cases of WPV1 and WPV3 from environmental samples had dates of collection in May 2014 (Kaduna) and July 2012 (Kano) respectively [4].

ES was initiated in Gombe State in December 2016. Four ES sites were identified and sample collection began soon after training of personnel responsible for collection of the sewage sample. The four identified ES sites are Baba Roba Valley, Unguwauku Railway Bridge, Gadan Bayan Moonshine and Dan Gusau Bridge. Since inception of ES in Gombe State, 2 ambiguous Vaccine Derived Poliovirus type 2 (aVDPV2) were confirmed from sewage samples collected from Baba Roba Valley site on the 30th January 2017 and from Dan Gusau Bridge site on the 6th March 2017. In 2018, a circulating Vaccine Derived Poliovirus type 2 (cVDPV2) was also detected from sewage samples collected on the 9th April 2018 from Baba Roba Valley site. We reviewed the laboratory results from the 2 surveillance methods so as to evaluate the VDPV2 isolation rate.

\section{Methods}

ES involves collection of one litre of environmental sample (sewage water) via grab sampling method in accordance with World Health Organization's (WHO) Guidelines for Environmental Surveillance for Polioviruses [2]. All ES sewage samples were transported in a 1 litre container appropriately packaged in a Giostyle with 8 frozen icepacks to maintain reverse cold chain to a Polio Laboratory where the samples are analyzed as per WHO ES testing standard operating procedures. Poliovirus type 2 isolates are sent to the reference laboratory at the US Centre for Disease Control for sequencing for PV isolation.

We reviewed all the results of the environmental samples (ES) and stool samples from patients with Acute flaccid paralysis (AFP) from January 2017 to June 2018. The environmental samples were from five pre-selected sites that was based on the perceived risks for polio circulation that included poor sanitation, overcrowding, extend of drainage population, availability of sewage system and absence of discharge into the sites. The stool samples were from patients detected with AFP in Gombe local government area.

The results from the two methods of surveillance for PV were evaluated and compared based on yields and isolates (Negative results, VDPV2, Non-polio enterovirus (NPENT).

ISDS Annual Conference Proceedings 2019. This is an Open Access article distributed under the terms of the Creative Commons AttributionNoncommercial 4.0 Unported License (http://creativecommons.org/licenses/by-nc/3.0/), permitting all non-commercial use, distribution, and reproduction in any medium, provided the original work is properly cited. 


\section{Results}

A total of 309 sewage samples from five [5] sites and 142 AFP stool samples from Gombe LGA were collected from January 2017 to June 2018. Three 3(0.97\%) of the sewage samples yielded VDPV2, 102(33.01\%) had Non-polio enteroviruses (NPENT) and 41 $(13.27 \%)$ negative samples. On the other hand, no VDPV was isolated from the AFP stool samples, the NPENT detection rate was $13(9.16 \%)$ and $121(85.21 \%)$ samples were negative. The Non-polio AFP (NPAFP) and stool adequacy rates for Gombe LGA during the reporting period were calculated to be 17.2 and $100 \%$ respectively.

\section{Conclusions}

The polio virus (VDPV) isolation from ES in this review is higher than in AFP surveillance. This has demonstrated amongst others benefit of ES its ability to detect polio virus even in the absence of the virus among AFP cases. ES can thus detect virus that are probably missed by AFP surveillance and hence allow for early response so as to curtail further transmission. The high NPAFP and stool adequacy rates are indication of a sensitive surveillance system nonetheless, the virus isolation from the AFP surveillance was very low. It is important to mention here that other laboratory indicators were not factored into this review. We recommend therefore that both ES and AFP surveillance be done together where facility, resources and personnel are available to implement

\section{Acknowledgement}

We sincerely acknowledge the Gombe State Ministry of Health, Gombe State Primary Health Care Development Agency, all Sample collectors and State Data Assistance W.H.O Gombe office for their support and information sharing during this review.

\section{References}

1. WHO. Field guide for supplementary activities aimed at achieving polio eradication, publication no. WHO/ EPI/GEN/95.1. Geneva: World Health Organization, 1995.

2. WHO. Guidelines for environmental surveillance of poliovirus circulation. World Health Organization 2003, Department of Vaccines and Biologicals, 2003. (http://www.who.int/vaccines-documents/DoxGen/H5-Surv. htm). Accessed 6 October 2010.

3. Gumede N, et al. 2015. Status of environmental surveillance in the African Regional. Afr Health Monit. (19), $38-41$.

4. Muluh TJ, et al. 2016. Contribution of Environmental Surveillance Toward Interruption of Poliovirus Transmission in Nigeria, 2012-2015. J Infect Dis. 213(Suppl 3), S131-35. https://doi.org/10.1093/infdis/jiv767 PubMed

5. Asghar H, et al. 2014. Environmental Surveillance for Polioviruses in the Global Polio Eradication Initiative. $J$ Infect Dis. 210(Suppl 1), S294-303. doi:https://doi.org/10.1093/infdis/jiu384. PubMed

Table 1. Summary of result from five (5) ES sites and AFP Stool Samples in Gombe LGA January 2017 - June 2018

\begin{tabular}{|c|c|c|c|c|c|c|c|c|c|c|}
\hline Name of ES Site & $\begin{array}{c}\text { NO. of AFP } \\
\text { cases }\end{array}$ & $\begin{array}{c}\text { NO. of sewage/ } \\
\text { stool samples } \\
\text { collected }\end{array}$ & VDPV2 & Sabin & NPENT & Negative & $\begin{array}{l}\text { Sabin }+ \\
\text { NPENT }\end{array}$ & Sabin 2 & $\begin{array}{c}\text { NPAFP } \\
\text { Rate }\end{array}$ & $\begin{array}{r}\% \text { stool } \\
\text { Adequacy }\end{array}$ \\
\hline Baba Roba Valley & - & 66 & 2 & 14 & 18 & 3 & 16 & 13 & - & - \\
\hline Dan Gusau Bridge & - & 65 & 1 & 12 & 21 & 10 & 9 & 12 & - & - \\
\hline $\begin{array}{c}\text { UnguwaUku } \\
\text { Railway Bridge }\end{array}$ & - & 64 & 0 & 4 & 27 & 12 & 10 & 11 & - & - \\
\hline $\begin{array}{c}\text { Gadan Bayan } \\
\text { Moonshine }\end{array}$ & - & 65 & 0 & 18 & 17 & 5 & 14 & 11 & - & - \\
\hline Unguwan Bari Bari & - & 49 & 0 & 7 & 19 & 11 & 7 & 5 & - & - \\
\hline
\end{tabular}

SDS Annual Conference Proceedings 2019. This is an Open Access article distributed under the terms of the Creative Commons AttributionNoncommercial 4.0 Unported License (http://creativecommons.org/licenses/by-nc/3.0/), permitting all non-commercial use, distribution, and reproduction in any medium, provided the original work is properly cited. 


\section{OJPHI}

ISDS 2019 Conference Abstracts

SDS

INTERNATIONAL SOCIETY

\begin{tabular}{|c|c|c|c|c|c||c|c|c||c|}
\hline ES Total (\%) & - & 309 & $3(1.0)$ & $55(17.8)$ & $102(33.0)$ & $41(13.3)$ & $56(18.1)$ & $52(16.8)$ & - \\
\hline AFP Stool Samples (\%) & 71 & 142 & $0(0)$ & $8(5.6)$ & $13(9.2)$ & 121 & $0(0)$ & $0(0)$ & 17.2 \\
& & & & & & 100 \\
\end{tabular}

SDS Annual Conference Proceedings 2019. This is an Open Access article distributed under the terms of the Creative Commons AttributionNoncommercial 4.0 Unported License (http://creativecommons.org/licenses/by-nc/3.0/), permitting all non-commercial use, distribution, and reproduction in any medium, provided the original work is properly cited.

Online Journal of Public Health Informatics * ISSN 1947-2579* http://ojphi.org * 11(1): e325, 2019 